\title{
Development of an indirect ELISA to detect Corynebacterium pseudotuberculosis specific antibodies in sheep employing T1 strain culture supernatant as antigen ${ }^{1}$
}

\author{
Miriam F. Rebouças ${ }^{2}$, Dan Loureiro², Bruno L. Bastos², Lilia F. Moura-Costa ${ }^{3}$, \\ Samira A. Hanna ${ }^{3}$, Vasco Azevedo ${ }^{4}$, Roberto Meyer ${ }^{2}$ and Ricardo W. Portela ${ }^{2 *}$
}

\begin{abstract}
Rebouças M.F., Loureiro D., Bastos B.L., Moura-Costa L.F., Hanna S.A., Azevedo V., Meyer R. \& Portela R.W. 2013. Development of an indirect ELISA to detect Corynebacterium pseudotuberculosis specific antibodies in sheep employing T1 strain culture supernatant as antigen. Pesquisa Veterinária Brasileira 33(11):1296-1302. Laboratório de Imunologia e Biologia Molecular, Instituto de Ciências da Saúde, Universidade Federal da Bahia, Av. Reitor Miguel Calmon s/n, Vale do Canela, Salvador, BA 40110-100, Brazil. Email: rwportela@gmail.com

Corynebacterium pseudotuberculosis is the etiologic agent of caseous lymphadenitis (CLA), a chronic disease that affects goats and sheep, characterized by granuloma formation in subcutaneous and internal lymph nodes. CLA causes significant economic losses to commercial goat herds. In this study, we aimed to test secreted antigens secreted from T1 strain bacteria grown in brain heart infusion (BHI) broth in an indirect ELISA system to determine the presence of specific immunoglobulins against $C$. pseudotuberculosis. We analyzed the BHI antigen electrophoretic profile and the recognition pattern by infected sheep sera samples. The ELISA results were compared with multiplex PCR assay and IFN-gamma production. The ELISA was able to discriminate between negative and positive animals, with a sensitivity of $89 \%$ and a specificity of $99 \%$, using microbiological isolation as gold standard. When this assay was compared with multiplex PCR and specific IFN-gamma quantification, six discrepant results were found among thirty-two samples. We concluded that the ELISA using antigens secreted from C. pseudotuberculosis T1 strain growth in BHI broth culture can be used for the serodiagnosis of CLA in sheep.
\end{abstract}

INDEX TERMS: Caseous lymphadenitis, Corynebacterium pseudotuberculosis, sheep, ELISA.

\begin{abstract}
RESUMO.- [Desenvolvimento de ELISA indireto para detectar anticorpos específicos contra Corynebacterium pseudotuberculosis em ovinos utilizando o supernadante de cultura da cepa T1 como antígeno.] Corynebacterium pseudotuberculosis é o agente etiológico da linfadenite caseosa (LC) uma doença crônica que afeta ovinos e
\end{abstract}

\footnotetext{
${ }^{1}$ Received on June 21, 2013.

Accepted for publication on September 12, 2013

${ }^{2}$ Laboratório de Imunologia e Biologia Molecular, Instituto de Ciências da Saúde, Universidade Federal da Bahia (UFBA), Av. Reitor Miguel Calmon s/n, Vale do Canela, Salvador, BA 40110-100, Brazil. *Corresponding author: rwportela@gmail.com

${ }^{3}$ Laboratório de Microbiologia, Instituto de Ciências da Saúde, UFBA, Salvador, BA.

${ }^{4}$ Laboratório de Genética Molecular e Celular, Instituto de Ciências Biológicas, Universidade Federal de Minas Gerais (UFMG), Av. Antônio Carlos 6627, Pampulha, Belo Horizonte, MG 31270-910, Brazil.
}

caprinos caracterizada pela formação de granulomas em linfonodos. A LC causa perdas econômicas significativas em criações de pequenos ruminantes. Este trabalho teve como objetivo testar antígenos secretados da cepa T1 da bactéria em um sistema de ELISA indireto para detecção de anticorpos específicos contra C. pseudotuberculosis. 0 perfil eletroforético do antígeno foi analisado, bem como o padrão de reconhecimento por soros de animais infectados. Os resultados do ELISA foram comparados com ensaio de multiplex PCR e com teste de indução de produção específica de IFN-gama. O ELISA foi capaz de discriminar animais positivos de animais negativos, com sensibilidade de $89 \%$ e especificidade de 99\%, usando o isolamento microbiológico como padrão ouro. Quando o ensaio foi comparado com o multiplex PCR e a produção específica de IFN-gama, somente seis resultados discrepantes foram encontrados em trinta e duas amostras. Pode-se concluir que o ensaio 
de ELISA desenvolvido pode ser utilizado com alto grau de confiança para o diagnóstico da LC em ovinos.

TERMOS DE INDEXAÇÃO: Linfadenite caseosa, Corynebacterium pseudotuberculosis, ovinos, ELISA.

\section{INTRODUCTION}

Caseous lymphadenitis (CLA) is an infectious disease that affects goats and sheep (Pepin et al. 1999); it is caused by the facultative intracellular bacteria Corynebacterium pseudotuberculosis and is characterized by granulomas in superficial lymph nodes, lungs, liver and spleen. The disease is endemic in northeastern Brazil and causes significant economic losses because of mortality and reduced weight gain and milk production (Unanian et al. 1985).

Currently, CLA diagnosis in small ruminants is based on characteristic clinical symptoms and on the microbiological identification of C. pseudotuberculosis in material taken from abscesses. However, efficient control requires serological diagnosis, because infected animals that have no apparent symptoms are a source of infection to healthy animals (Kaba et al. 2001).

Numerous serological tests have been developed to detect antibodies against $C$. pseudotuberculosis in small ruminants, but no test has been found to be satisfactory when applied alone (Paton et al. 1995). Various antigen preparations have been assayed in ELISA tests, including bacterial culture supernatants (Seyffert et al. 2010); cell wall antigens (Maky et al. 1985, Sutherland et al. 1987); phospholipase D exotoxin (Ter Laak et al. 1992, Dercksen et al. 2000); and recombinant exotoxins (Menzies et al. 1994).

Typically, tests work well for goats (Dercksen et al. 2000, Kaba et al. 2001, but they have reduced sensitivity in sheep, especially in subclinical infection that have only internal abscesses. These ELISA tests are not commercially available, and those that are available are relatively costly (Binns et al. 2007).

In this study, secreted antigens from C. pseudotuberculosis strain $\mathrm{T} 1$ grown in brain heart infusion (BHI) broth culture were tested in an indirect ELISA for the detection of $C$. pseudotuberculosis-specific antibodies in sheep. The standardization parameters and the humoral immune recognition of the antigen are also presented.

\section{MATERIALS AND METHODS}

\section{Samples}

To test the ELISA assay and establish its parameters, 70 serum samples were obtained from sheep of commercial flocks, presenting external lesions typical of CLA. Caseous material was obtained through biopsy, and the etiologic agent was isolated by microbiological techniques, as described below. As negative controls, 112 serum samples were obtained from animals with no clinical history of CLA, from a non-endemic area where the disease has been controlled. Samples were stored at $-20^{\circ} \mathrm{C}$ until use.

With the objective to compare the developed ELISA with bacterial DNA identification and interferon-gamma (INF-y) quantification, we used samples from other 32 sheep with granulomatous lesions characteristic of CLA. Caseous material from these lesions was aseptically collected for bacterial DNA identification by multiplex PCR. Blood was collected in heparinized tubes for interferon- -gamma (INF-y) quantification, and in tubes without anticoagulant for the ELISA assay.

Three serum samples from sheep presenting external lesions with $C$. pseudotuberculosis presence confirmed by microbiological identification (CLA clinically ill animals); three samples from sheep with no clinical sign of the disease, but with positive ELISA results (CLA subclinically infected animals); and two serum samples from animals from non-endemic areas with no clinical history of CLA (negative samples) were tested in a Western blotting system aiming to verify the pattern of antigen recognition.

\section{Bacterial identification}

Caseous samples were aseptically collected and plated onto Brain Heart Infusion (BHI) blood agar; the bacteria were identified based on colony morphology, Gram staining, catalase and urease activity, carbohydrate fermentation (glucose, lactose, sucrose and maltose), and synergistic hemolytic activity with Christie, Atkins, Munch-Peterson (CAMP) factor of Rhodococcus equi, as already described (Dercksen et al. 2000).

\section{Corynebacterium pseudotuberculosis $\mathrm{T} 1$ strain secreted anti- gen production}

The antigen was produced as already described (Moura-Costa et al. 2008). Briefly, C. pseudotuberculosis T1 strain (INCQS 00512) was cultivated in $\mathrm{BHI}$ broth at $37^{\circ} \mathrm{C}$ for $48 \mathrm{~h}$. The culture material was then centrifuged at $10,000 \mathrm{~g}$ for $30 \mathrm{~min}$ and the supernatant was filtered through a $0.22 \mu \mathrm{m}$ membrane filter. This supernatant was maintained at $-20^{\circ} \mathrm{C}$ until use. Protein concentration was determined using the RC DC Protein Assay kit (Bio-Rad Laboratories, Hercules, USA). This antigen was used in the ELISA.

\section{Three-phase partitioning (TPP) technique for BHI antigen concentration}

The BHI antigen was concentrated using the TPP technique, as already described (Paule et al. 2004), with the objective to verify its composition in an electrophoresis system. It was analyzed by SDS-PAGE electrophoresis and employed in blood cell culture stimulation. Briefly, 15\% ammonium sulfate was added to BHI culture supernatants obtained as previously described, and the mixture was gently stirred at room temperature. The $\mathrm{pH}$ was adjusted by adding a concentrated $\mathrm{HCl}$ solution; then the same volume of n-butanol was added. The mixture was vortexed for $1 \mathrm{~min}$ and allowed to rest for $1 \mathrm{~h}$. This mixture was centrifuged at $1350 \mathrm{xg}$ for $10 \mathrm{~min}$, and the interfacial precipitation was collected and dissolved in a small volume of Tris $20 \mathrm{mM} \mathrm{pH} 7.4$ buffer $(500 \mu \mathrm{l}$ buffer $/ 5 \mathrm{ml}$ culture supernatant). The extracts were dialyzed by ultra-filtration with a $10 \mathrm{KDa}$ cut-off membrane (Millipore Corp., Billerica, USA) against Tris $20 \mathrm{mM}$, pH 7.4. The protein content of the extracts was determined using the RC DC Protein Assay kit (Bio-Rad Laboratories, Hercules, USA).

\section{Polyacrylamide gel electrophoresis (SDS-PAGE)}

C. pseudotuberculosis secreted antigens were concentrated by three-phase partitioning (TPP) technique and separated by one-dimensional polyacrylamide gel electrophoresis under denaturing conditions. A discontinuous SDS-PAGE system with a $4 \%$ stacking gel and a 12\% running gel was used. Electrophoresis was performed in $0.124 \mathrm{M}$ Tris, $0.96 \mathrm{M}$ glycine, and $0.5 \%$ SDS pH 8.3 migration buffer, at $100 \mathrm{~V}$ for $3 \mathrm{~h}$. Each well was loaded with $50 \mu \mathrm{g}$ of protein. Proteins were observed by Coomassie Blue staining.

ELISA for the detection of specific immunoglobulins against Corynebacterium pseudotuberculosis

ELISA assay was developed based on a checkerboard procedure; the working dilution of the horseradish peroxidase-conju- 
gated anti-sheep IgG immunoglobulin; the optimum protein concentration of antigen solution; and the serum sample dilutions were determined by previous checkerboard titrations in order to achieve suitable differentiation between positive and negative sera samples. Sera were tested at 1:25, 1:50, 1:100, 1:200, 1:400, and 1:800 dilutions; antigen at 1:400, 1:200, 1:100, 1:50, and 1:25 dilutions; and the secondary antibody was assayed at $1: 5000,1: 10,000,1: 20,000,1: 40,000$, and $1: 80,000$ dilutions (data not shown). The same C. pseudotuberculosis-positive (from animals with CLA confirmed by microbiological isolation) and negative (from non-endemic area animals) control serum samples were used as standards in all assays aiming to ensure reliability and reproducibility of results. The antigen, serum and anti-sheep IgG dilution chosen presented a positive/negative optical density (OD) ratio of 12.6 .

High binding polystyrene microplates (Corning Life Sciences, Lowell, USA) were sensitized with BHI C. pseudotuberculosis T1 strain culture supernatant antigen diluted 1:100 in carbonate-bicarbonate $\mathrm{pH} 9.6$ buffer and incubated at $4^{\circ} \mathrm{C}$ for $12 \mathrm{~h}$. The plates were then washed twice with PBS $0.05 \%$ Tween 20 (PBST), blocked with $5 \%$ skimmed milk in PBST, and incubated at $37^{\circ} \mathrm{C}$ for $2 \mathrm{~h}$. After two additional washes with PBST, $100 \mu \mathrm{l}$ of serum samples diluted 1:100 in PBST 1\% skimmed milk were added and the plates were incubated at $37^{\circ} \mathrm{C}$ for $1 \mathrm{~h}$. Each serum was tested in duplicate. Plates were washed four times with PBST and a rabbit anti-ovine IgG antibody conjugated with horseradish peroxidase (Serotec, Raleigh, USA) diluted 1:20,000 was added and incubated at $37^{\circ} \mathrm{C}$ for $45 \mathrm{~min}$. After this incubation, the plates were washed and the reaction was developed with $100 \mu \mathrm{l} /$ well of a solution containing $\mathrm{H}_{2} \mathrm{O}_{2}$ and tetramehtylbenzidine (Moss Inc., Pasadena, USA) for 15 minutes, and stopped with $4 \mathrm{~N} \mathrm{H}_{2} \mathrm{SO}_{4}$. Results were then read in an ELISA plate reader (Bio-Rad Laboratories, Hercules, USA) at $450 \mathrm{~nm}$.

\section{Western-blot for the detection of proteins recognized by sera from sheep with clinical caseous lymphadenitis}

The ELISA antigens were separated by SDS-PAGE electrophoresis and transferred to nitrocellulose membranes using $100 \mathrm{~V}$ for $1 \mathrm{~h}$; the membranes were temporarily stained with Ponceau's stain to ensure that the transference process was successful. The membranes were blocked with 5\% dry skimmed milk in $0.05 \%$ PBS-Tween 20 overnight at $4^{\circ} \mathrm{C}$. They were then incubated with 1:50 sera from CLA clinically, subclinically ill or seronegative sheep, diluted in PBS-Tween buffer containing 1\% dry skimmed milk, at $37^{\circ} \mathrm{C}$ for $1 \mathrm{~h}$, washed five times in $0.05 \%$ PBS-Tween buffer, and incubated for $1 \mathrm{~h}$ with horseradish-peroxidase conjugated rabbit anti-sheep immunoglobulins (Serotec, Raleigh, USA) diluted 1:200 in PBS-Tween. Membrane strips were washed five times in $0.05 \%$ PBS-Tween and revealed using substrate developer solution (4-chloro-1-naphthol 0.3\%, hydrogen peroxide). The reaction was stopped with a final rinse in distilled water and the strips were dried and scanned.

\section{Multiplex-PCR for identification of Corynebacterium pseudo- tuberculosis in caseous material}

A species-specific Multiplex-PCR based on the amplification of three different genomic regions, including a fraction of the gene responsible for the expression of the exotoxin phospholipase D, was performed as already described (Pacheco et al. 2007). Briefly, bacterial cultures from caseous material retrieved from animals with clinical CLA, as described in the previous item, were transferred to a liquid BHI culture medium and incubated at $37^{\circ} \mathrm{C}$ for $48 \mathrm{~h}$. The culture material was centrifuged and the pellet was subjected to DNA extraction using a commercial kit (Phoneutria, Belo Horizonte, Brazil). The DNA samples were then quantified in a spectrophotometer (Bio-Rad Laboratories, Hercules, USA) at 260 and $280 \mathrm{~nm}$.

Multiplex PCRs were performed in a final reaction volume of $10 \mu \mathrm{l}$ containing 1.5UI AccuPrime Taq DNA polymerase, PCR Buffer II [200 mM Tris/HCl, $500 \mathrm{mM} \mathrm{KCl,} 15 \mathrm{mM} \mathrm{MgCl2,} 2 \mathrm{mM} \mathrm{dN}-$ TPs, 10\% glycerol] (Invitrogen, Carlsbad, USA) and $2 \mathrm{mM}$ of each of the 16S-F/16S-R, C2700F/C3130R, and PLD-F/PLDR2 primers. The template concentration was approximately 30ng of DNA extracted from cultured C. pseudotuberculosis. Reactions were carried out in a thermal cycler (MJ Research, Waltham, USA) under the following conditions: initial denaturation at $95^{\circ} \mathrm{C}$ for $3 \mathrm{~min}$; 40 cycles of $95^{\circ} \mathrm{C}$ for $1 \mathrm{~min}, 58^{\circ} \mathrm{C}$ for $40 \mathrm{~s}$, and $68^{\circ} \mathrm{C}$ for $1 \mathrm{~min}$ and $30 \mathrm{~s}$; final extension at $68^{\circ} \mathrm{C}$ for $7 \mathrm{~min}$. The amplified products were resolved by electrophoresis on $1.0 \%(\mathrm{w} / \mathrm{v})$ agarose gels and visualized by ethidium bromide staining.

\section{IFN-gamma quantification}

Quantification of INF-gamma in blood cultures was performed for samples collected from thirty-two infected sheep, as already described (Paule et al. 2003, Meyer et al. 2004) with some modifications. Briefly, $2 \mathrm{~h}$ after collection, heparinized blood was incubated at $37^{\circ} \mathrm{C}$ for $48 \mathrm{~h}$ in a humidified $5 \% \mathrm{CO}_{2}$ atmosphere in a 24-well culture tray with $20 \mu \mathrm{g}$ of antigen concentrated using TPP technique; $5 \mu \mathrm{l}$ of pokeweed mitogen was used as a positive control and sterile PBS was used as a negative control. The blood was centrifuged and IFN-gamma was quantified using an Ovine IFN-gamma kit (MabTech AB, Nacka Strand, Sweden). Cut-off point was calculated using the mean of all not-stimulated cell results, plus three standard deviations. All results greater than this value (198 pg/ml) were considered significant.

\section{Statistical and mathematical analysis}

The cut-off point was calculated as already described (Frey et al. 1998), with a confidence interval of $99.8 \%$; it corresponded to the mean of all negative sera optical densities (OD) plus three standard deviations.

The sensitivity (S), specificity (E), and accuracy of the ELISA assay were calculated as follows: $\mathrm{S}=[\mathrm{TP} /(\mathrm{TP}+\mathrm{FP})] \times 100 ; \mathrm{E}=$ $[\mathrm{TN} /(\mathrm{TN}+\mathrm{FN})] \times 100 ; \mathrm{A}=[(\mathrm{FN}+\mathrm{FP} /(\mathrm{TP}+\mathrm{TN})] \times 100$. Where, $\mathrm{TP}$ $=$ the number of truly positive samples, $\mathrm{TN}=$ the number of truly negative samples, FP = the number of false-positive samples, and $\mathrm{FN}=$ the number of false-negative samples (Seyffert et al. 2010). The microbiological isolation of $C$. pseudotuberculosis was used as the gold standard.

Repeatability (RP) was calculated testing each positive and negative controls 40 times within the same day and under the same conditions, employing the calculated variation coefficient (CV) found for optical density values as follows: $R P=(1-C V) \times 100$.

The levels of statistical agreement between diagnostic assays were detected using the Kappa coefficient. The concordance was classified as follows: <0 - no agreement; 0.19 - poor agreement; 0.20-0.39 - fair agreement; 0.40-0.59 - moderate agreement; 0.600.79 - substantial agreement; and 0.80-1.00 - almost perfect agreement (Landis \& Koch 1977).

\section{RESULTS}

In the SDS-PAGE electrophoresis of the BHI antigen, concentrated by the TPP technique (Fig.1), the antigen solution presented a complex pattern with various molecules. Two antigens predominated (105 and $130 \mathrm{KDa}$ ). In the Western-blot, the BHI antigen was resolved on an SDS-PAGE gel, transferred to a nitrocellulose membrane, and incubated with sera from seronegative animals, from seropositive animals with no clinical manifestations of caseous 
$\mathbf{1}$

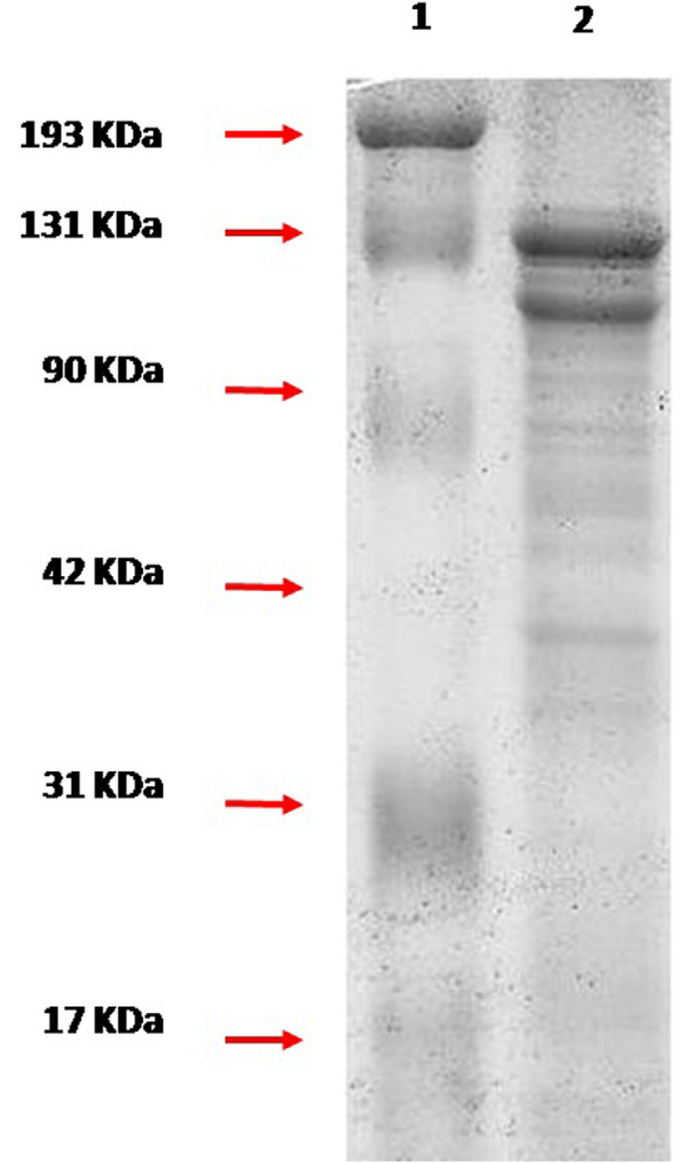

Fig.1. SDS-PAGE electrophoresis profile of Corynebacterium pseudotuberculosis antigen from brain heart infusion broth $C$. pseudotuberculosis $\mathrm{T} 1$ strain culture supernatant, concentrated using the three-phase partitioning technique. (1) Molecular weight standard; (2) C. pseudotuberculosis antigen (50 $\mu \mathrm{g})$. Staining with Coomassie Brilliant Blue. Numbers on the left indicate the molecular weight values for the protein standard.

lymphadenitis (CLA subclinically ill animals), and from seropositive animals with external granulomatous lesions with confirmed Corynebacterium pseudotuberculosis (CLA clinically ill animals) (Fig.2). No reaction was observed in strips incubated with sera from negative animals. Sera from seropositve animals without clinical disease showed marked recognition of a 70KDa antigen and discrete recognition of a 32KDa antigen. Animals with clinical manifestations of disease also had antibodies specific for the $70 \mathrm{KDa}$ antigens, but they manifested a stronger humoral reaction to the $32 \mathrm{Kda}$ antigen.

Table 1 presents the validation criteria for the ELISA assay and the number of sera employed for this standardization. ELISA presented only one false-positive result, showing specificity of $99 \%$. However, nine sera from animals with CLA confirmed by microbiological assays showed negative results; therefore the sensitivity was $89 \%$. These results were calculated based on a cut-off point of OD 0.250 . In addition, the method was quite stable, since repeatability was $93.2 \%$ for the higher values (positive control) and $97.3 \%$ for the lower values (negative control).

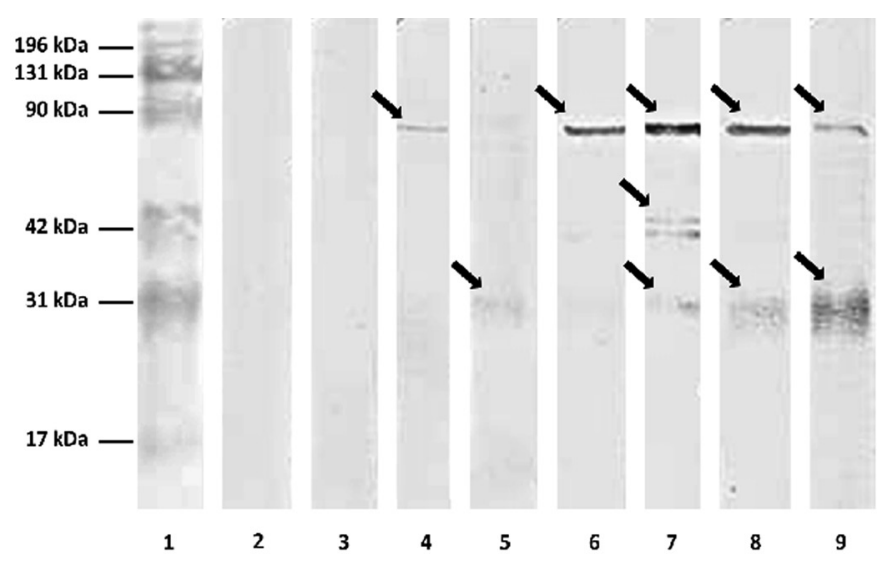

Fig.2. Western blotting profile of Corynebacterium pseudotuberculosis $\mathrm{T} 1$ strain antigen from brain heart infusion culture supernatant, resolved by SDS-PAGE and incubated with negative ovine sera, sera from sheep with subclinical infection (seropositive by ELISA, but without external symptoms) and samples from animals with clinical caseous lymphadenitis (CLA) (seropositive by ELISA with caseous lesions). (1) Molecular weight standard; (2) and (3) negative sera; (4), (5) and (6) seropositive animals, without clinical signs of CLA; (7), (8) and (9) seropositive animals with caseous lesions. Numbers on the left indicate the values of molecular weights from the protein standard in KDa. Arrows indicate the bands recognized by serum antibodies.

Table 1. Validation parameters found for the ELISA developed for identification of specific antibodies against Corynebacterium pseudotuberculosis. Microbiological isolation of $C$. pseudotuberculosis was used as gold standard

\begin{tabular}{lc}
\hline \multicolumn{1}{c}{ Parameter } & Result \\
\hline Number of tested sera & 182 \\
Number of truly positive sera & 69 \\
Number of truly negative sera & 103 \\
Number of false-positives & 1 \\
Number of false-negatives & 9 \\
Cut-off & 0.250 \\
Sensitivity (\%) & $89 \%$ \\
Specificity (\%) & $99 \%$ \\
Accuracy (\%) & $94.5 \%$ \\
Repeatability (negative control) & $97.3 \%$
\end{tabular}

In the distribution of ELISA results based on OD ranges (Fig.3), the known positive sera showed normal distribution with peaks within the range of 0.400 to 0.500 . Known negative samples were mostly (nearly $70 \%$ ) below OD 0.100 ; a small percentage of these negative-sample ODs were near the cut-off point $(0.250)$. The mean of the negative samples was 6.5 times lower than the mean of the positive samples. Figure 4 shows the distribution of optical densities individually for each animal. There was only one positive result above the cut-off point employed for a seronegative animal.

A comparison was made between immunological and molecular techniques for the diagnosis of CLA (Table 2). Multiplex-PCR, which was designed to amplify three different $C$. pseudotuberculosis genomic regions, including a fraction of the gene responsible for phospholipase D exotoxin expression, was able to identify 25 positive samples. Only two of these samples were negative in the ELISA assay, 


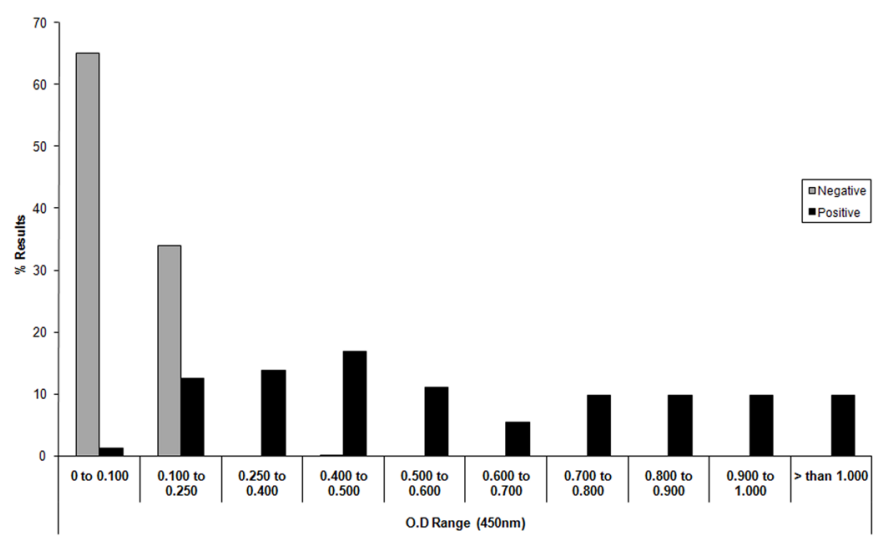

Fig.3. Distribution of the optical density (OD) results from the ELISA for the detection of specific antibodies against Corynebacterium pseudotuberculosis. Data express results obtained with 120 negative sera and 70 positive sera, divided by the percentage in each range. The cut-off point employed was 0.250 OD.

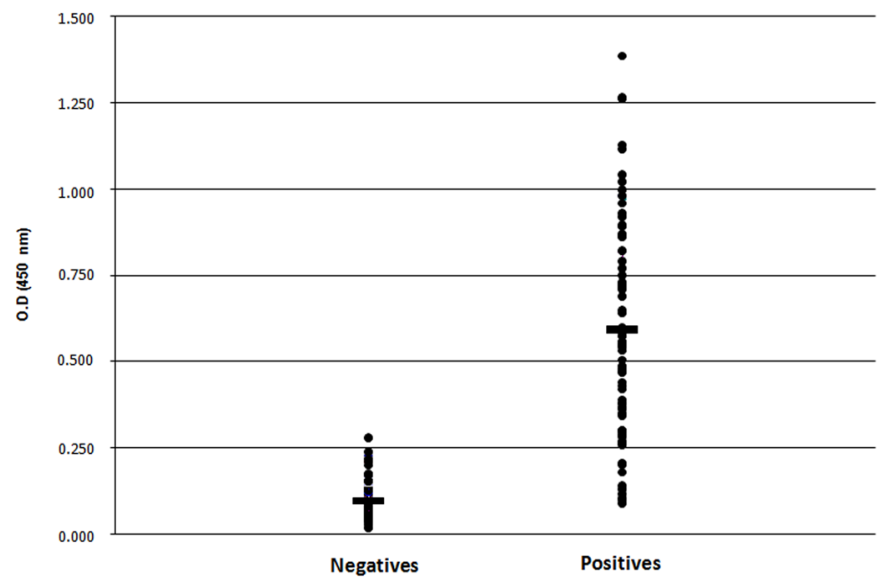

Fig.4. Distribution of the optical density results obtained in the ELISA for the detection of specific antibodies against Corynebacterium pseudotuberculosis, organized by infection status (positive or negative). Data express results obtained with 112 and 70 sera from infected and non-infected animals. The calculated cut-off point was 0.250 . Bars indicate the means of optical densities for each group.

Table 2. Comparison between multiplex PCR, ELISA, and IFN-gamma assay results using caseous samples, sera, and whole blood samples from 32 animals with suggestive clinical signs

\begin{tabular}{lccc}
\hline & Positive by ELISA & Negative by ELISA & Total \\
\hline $\begin{array}{l}\text { Positive by PCR and } \\
\text { IFN-gamma }\end{array}$ & 23 & 1 & 24 \\
$\begin{array}{l}\text { Positive by PCR and } \\
\text { Negative by IFN-gamma }\end{array}$ & 1 & 0 & 1 \\
$\begin{array}{l}\text { Negative by PCR and } \\
\text { Positive by IFN-gamma }\end{array}$ & 5 & 0 & 5 \\
$\begin{array}{l}\text { Negative by PCR and } \\
\text { IFN-gamma }\end{array}$ & 1 & 1 & 2 \\
TOTAL & 30 & 2 & 32
\end{tabular}

while three of them presented low and non-significant INF-gamma production by peripheral blood cells.

When we considered the results of the diagnostic methods altogether, only one sample was negative for all te- chniques. Four animals were negative for bacterial DNA identification, but showed positive results in ELISA and IFN-gamma. Two animals presented discrepant results in the ELISA, when compared with the other methodologies; one was positive in the ELISA, but negative in the other assays, and one was negative in the ELISA, but positive in the IFN-y quantification and bacterial DNA identification.

The Kappa correlation index results calculated in the comparison of the diagnostic assays are shown in Table 3. Only the correlations between IFN-gamma and PCR, and ELISA and IFN-gamma quantification showed fair agreement results; all the others were classified as correlations with poor or no agreement.

Table 3. Statistical results for the Kappa's correlation index in the comparison of immunologic and molecular assays employed for the validation of the ELISA assay

\begin{tabular}{lcc}
\hline Compared assays & Kappa's coefficient & Interpretation \\
\hline ELISA X IFN-gamma & 0.351 & Fair agreement \\
ELISA X PCR & 0.138 & No agreement \\
IFN-gamma X PCR & 0.309 & Fair agreement
\end{tabular}

\section{DISCUSSION}

First, the antigenic composition of the antigen used in the ELISA was analyzed. The culture supernatant of T1 strain of Corynebacterium pseudotuberculosis has already been analyzed (Paule et al. 2004), and it was found that serum antibodies of infected goats recognized several antigens, ranging from 16 to $125 \mathrm{KDa}$. Several proteins were found in the $C$. pseudotuberculosis T1 strain culture supernatant, with prevalence of the 105 and 130KDa bands recognition (Fig.1). But when the humoral recognition of these antigens by Western blotting was examined, sera from animals with clinical disease (presenting caseous lesions caused by $C$. pseudotuberculosis) recognized antigens with molecular weights of 32 and $70 \mathrm{KDa}$, while sera from animals with no clinical symptoms of CLA but presenting positive serological results (subclinically infected animals), reacted strongly to the $70 \mathrm{KDa}$ antigen, but weakly recognized the $32 \mathrm{KDa}$ protein (Fig.2). It is highly probable that this $32 \mathrm{KDa}$ antigen corresponds to the $31.5 \mathrm{KDa}$ fraction that has been characterized as the major secreted antigen of C. pseudotuberculosis, Phospholipase D (PLD) (Ellis et al. 1991, Costa et al. 1998). Phospholipase $D$ is an exotoxin responsible for the dissemination of bacteria in infected animals, and it is a virulence factor related to the formation of caseous lesions (Hodgson et al. 1992). Consequently, the low level of specific antibodies against this enzyme in animals with no clinical signs of disease probably occurs because of the low production of exotoxin by the bacteria or poor humoral immune activation. The 70KDa antigen that was well recognized by both clinical and subclinical animals may be the 67KDa protein described by other authors (Sting et al. 1998, Paule et al. 2003, Moura-Costa et al. 2008); it is classified as a heat shock protein (Ellis et al. 1991).

We used a large number of ovine serum samples $(112$ negative samples and 70 positive samples) to establish these parameters, which showed $99 \%$ specificity and $89 \%$ 
sensitivity (Table 1). Similar values were already obtained (Seyffert et al. 2010) employing the same antigen material in the development of ELISA tests to identify specific antibodies against $C$. pseudotuberculosis in goats; they attained $98.5 \%$ specificity and $93.5 \%$ sensitivity. Our results demonstrate advance and improvement over the ELISA assays developed for ovine CLA so far, since the other scientific reports indicated lower sensitivity. A sonicated somatic antigen was already employed in an ELISA methodology (Binns et al. 2007), showing 100\% specificity and 71\% sensitivity. In an attempt to enhance the sensitivity of an ELISA that uses $C$. pseudotuberculosis exotoxin as antigen, Deckersen et al. (2000) developed four different types of ELISA; the highest values obtained for sensitivity and specificity were 79 and 99\%, respectively. In this study, microbiological isolation and characterization of the bacteria was used as a gold standard for determining truly positive animals; but this methodology, besides demanding a long time, was not applied to subclinical infected animals that presented no external caseous lesions. Recently, Solanet et al. (2011) reported the development of an ELISA test to detect antibodies against $C$. pseudotuberculosis in vaccinated or infected sheep, presenting sensitivity and specificity of $98 \%$ and $100 \%$ respectively, but no evaluation of natural infected animals was conducted in this study.

The cut-off point established for the ELISA was calculated using a previously described methodology (Frey et al. 1998), which is a practical and reliable procedure that could be employed because numerous known negative sera samples were available. ROC curve was not applied, because the cut-off point calculated by the mentioned methodology (Frey et al. 1998) represents an intrinsic statistical and mathematical characteristic of the assay, not submitted to manipulations. We found repeatability of $93.2 \%$ for positive controls and $97.2 \%$ for negative controls, with high stability for the assay, since these numbers indicate the degree of concordance of results of a sample tested several times.

There were nine animals presenting symptoms of CLA with the bacteria confirmed by microbiological assays that presented negative results in the ELISA. These may be false-negative results, due to a problem with the sensitivity of this assay, but it must also be considered that some animals have very low production of antibodies against $C$. pseudotuberculosis, especially when the animal expresses a predominantly cellular response against the pathogen. Considering this situation, an IFN-gamma quantification after specific stimulation of peripheral blood leukocytes was already recommended (Prescott et al. 2002), in a test complementary to ELISA, in order to identify such animals. But even the IFN-gamma assay alone cannot be considered a reliable tool, since it was already reported that this test works well for goats, but lacks sensitivity when using sheep sera samples (Rebouças et al. 2011).

In order to validate our assay, ELISA results were compared with a highly sensitive multiplex PCR (Pacheco et al. 2007) and quantification of IFN-gamma after stimulation of peripheral blood leukocytes with secreted/excreted antigens of the bacteria. To this end, 32 samples from animals presenting caseous lesions, typical of CLA, were exa- mined. The results were quite satisfactory (Table 2). Only one animal that was identified as positive in MPCR and IFN-gamma assays showed a negative ELISA result, and it may represent an ELISA lack of sensitivity. In addition, one animal that showed negative results in the molecular and cellular immune response assays presented a positive result in the ELISA. Only one animal showed negative results for all three assays; this may be because of caseous lesions induced by other microorganisms, such as Arcanobacterium pyogenes or Pasteurella multocida (Deckersen et al. 2000, Dorella et al. 2006). Four animals showed positive results based on ELISA and IFN-gamma quantification, but were negative for bacterial DNA identification in the granulomatous lesion. This situation could be explained by a previous infection with $C$. pseudotuberculosis and a remaining memory immune response, and in the same way that was presented above the lesion analyzed could be caused by a phillogenetically related bacteria, as already seen before when a double-antibody sandwich was developed (Ter Laak et al. 1992). One animal showed positive results for ELISA, PCR and mPCR, but had low production of IFN-y; this animal may be a low producer of this cytokine (Prescott et al. 2002). The poor agreement found for the correlation of the ELISA assay with PCR and microbiological DNA identification could be explained by the fact that some animals in which $C$. pseudotuberculosis was not identified could have had CLA previously, with development of humoral and cellular responses, identified by ELISA and IFN-gamma quantification.

These results, when analyzed together, show the importance of the developed ELISA in the diagnosis of $C$. pseudotuberculosis infection in sheep during the chronic phase of the disease, because this is the moment that the caseous lesions are more likely to develop. The development and standardization of an ELISA for the detection of $C$. pseudotuberculosis IgM would also be useful for the diagnosis of the acute phase of the disease.

\section{CONCLUSIONS}

These results demonstrate the reliability and feasibility of using an indirect ELISA, employing T1 strain secreted antigen from a brain heart infusion broth culture supernatant, as an affordable tool to identify sheep infected by Corynebacterium pseudotuberculosis.

This immunodiagnostic assay could be employed in CLA control and eradication programs, with efficient detection of infected animals and reduced probability of elimination of false-positive animals.

Acknowledgments.- The authors are grateful to the Bahia State Agency for Animal Defense (ADAB) for the aid in the obtaining of serum samples; and to Francisca Soares and Danielle D. Lima (Labimuno-ICS/UFBA) for the technical assistance. This study was supported by Fapex, Fundece and Renorbio. R. Meyer and V. Azevedo are research fellows from CNPq. M.F. Rebouças and D.D. Lima are graduate students with scholarships granted by FAPEX, and D. Loureiro by CAPES.

\section{REFERENCES}

Binns S.H., Green L.E. \& Bailey M. 2007. Development and validation of an ELISA to detect antibodies to Corynebacterium pseudotuberculosis in ovine sera. Vet. Microbiol. 23:169-179. 
Costa L.R.R., Spier S.J. \& Hirsh D.C. 1998. Comparative molecular characterization of Corynebacterium pseudotuberculosis of different origin. Vet. Microbiol. 62:135-143.

Dercksen D.P., Brinkhof J.M., Dekker-Nooren T., Maanen K., Bode C.F., Baird G. \& Kamp E.M. 2000. A comparison of four serological tests for the diagnosis of caseous lymphadenitis in sheep and goats. Vet. Microbiol. 75:167-175

Dorella F.A., Pacheco L.G.C., Oliveira S.C., Myioshi A. \& Azevedo V. 2006. Corynebacterium pseudotuberculosis: microbiology, biochemical properties, pathogenesis and molecular studies of virulence. Vet. Res. 37:201-218.

Ellis J.A., Hawl D.A., Mills K.W. \& Pratt D.L. 1991. Antigen specificity of antibody responses to Corynebacterium pseudotuberculosis in naturally infected sheep with caseous lymphadenitis. Vet. Immunol. Immunopathol. 28:289-301.

Frey A., Di Canzio J. \& Zurakowski D.A. 1998. A statistically defined endpoint titer determination method for immunoassays. J. Immunol. Methods 221: $35-41$.

Hodgson A.L., Krywult J., Corner L.A., Rothel J.S. \& Radford A.J. 1992. Rational attenuation of Corynebacterium pseudotuberculosis - potential cheesy gland vaccine and live delivery vehicle. Infect. Immun. 60:2900-2905.

Kaba J., Kutschke L. \& Gerlach G.F. 2001. Development of an ELISA for the diagnosis of Corynebacterium pseudotuberculosis infections in goats. Vet. Microbiol. 78:155-163.

Landis J.R. \& Koch G.G. 1977. The measurement of observer agreement for categorical data. Biometrics 33:159-174.

Maky L.R., Shen S.H., Bergstrom R.C. \& Stetzenbach L.D. 1985. Diagnosis of Corynebacterium pseudotuberculosis infections in sheep, using an enzyme-linked immunossorbent assay. Am. J. Vet. Res. 46:212-214.

Menzies P.I., Muckle C.A., Hwang Y.T. \& Songer J.G. 1994. Evaluation of an enzyme-linked immunosorbent assay using an Escherichia coli recombinant phospholipase D antigen for the diagnosis of Corynebacterium pseudotuberculosis infection. Small Rumin. Res. 13:193-198.

Meyer R., Regis L., Vale V., Paule B., Carminati R., Bahia R., Moura-Costa L., Schaer R., Nascimento I. \& Freire S. 2004. In vitro IFN-gamma production by goat blood cells after stimulation with somatic and secreted Corynebacterium pseudotuberculosis antigens. Vet. Immunol. Immunopathol. 107:249-254.

Moura-Costa L.F., Bahia R.C., Carminati R., Vale V.L., Paule B.J., Portela R.W., Freire S.M., Nascimento I., Schaer R., Barreto L.M. \& Meyer R. 2008. Evaluation of the humoral and cellular immune response to different antigens of Corynebacterium pseudotuberculosis in Canindé goats and their potential protection against caseous lymphadenitis. Vet. Immunol. Immunopathol. 126:131-141.

Pacheco L.G., Pena R.R., Castro T.L., Dorella F.A., Bahia R.C., Carminati R., Frota M.N., Oliveira S.C., Meyer R., Alves F.S., Miyoshi A. \& Azevedo V. 2007. Multiplex PCR assay for identification of Corynebacterium pseudotuberculosis from pure cultures and for rapid detection of this pathogen in clinical samples. J. Med. Microbiol. 56:480-486.
Paton M.W., Sutherland S.S., Rose I.R., Hart R.A., Mercy A.R. \& Ellis T.M. 1995. The spread of Corynebacterium pseudotuberculosis infection to unvaccinated and vaccinated sheep. Aust. Vet. J. 72:266-269.

Paule B.J.A., Azevedo V., Regis L.F., Carminati R., Bahia C.R., Vale V.L., Moura-Costa L.F., Freire S.M., Nascimento I., Schaer R., Goes A.M. \& Meyer R. 2003. Experimental Corynebacterium pseudotuberculosis primary infection in goats: kinetics of IgG and interferon-gamma production, IgG avidity and antigen recognition by Western blotting. Vet. Immunol. Immunopathol. 96:129-139.

Paule B.J.A., Meyer R., Moura-Costa L.F., Bahia R.C., Carminati R., Regis L.F., Vale V.L., Freire S.M., Nascimento I., Schaer R. \& Azevedo V. 2004. Threephase partitioning as an efficient method for extraction/concentration of immunoreactive excreted-secreted proteins of Corynebacterium pseudotuberculosis. Protein Expr. Purif. 34:311-316.

Pepin M., Sanchis R. \& Paton M. 1999. La lymphadénite caséeuse des ovins et des caprins. Point Vet. 30:33-40.

Prescott J.F., Menzies P.I. \& Hwang Y.T. 2002. An interferon-gamma assay for diagnosis of Corynebacterium pseudotuberculosis infection in adult sheep from a research flock. Vet. Microbiol. 88:287-297.

Rebouças M.F., Portela R.W., Lima D.D., Loureiro D., Bastos B.L., Moura-Costa L.F., Vale V.L., Miyoshi A., Azevedo V. \& Meyer R. 2011. Corynebacterium pseudotuberculosis secreted antigen-induced specific gamma-interferon production by peripheral blood leukocytes: potential diagnostic marker for caseous lymphadenitis in sheep and goats. J. Vet. Diagn. Invest. 23:213-20.

Seyffert N., Guimarães A.S., Pacheco L.G., Portela R.W., Bastos B.L., Dorella F.A., Heinemann M.B., Lage A.P., Gouveia A.M., Meyer R., Miyoshi A. \& Azevedo V. 2010. High seroprevalence of caseous lymphadenitis in Brazilian goat herds revealed by Corynebacterium pseudotuberculosis secreted proteins-based ELISA. Res. Vet. Sci. 88:50-55.

Solanet J.J., Malena R., Estein S.M., Estevao Belchior S. \& Paolicchi F.A. 2011. Development of an ELISA test to detect antibodies in vaccinated sheep or infected Corynebacterium pseudotuberculosis. Revta Argent. Microbiol. 43:9-17.

Sting R., Steng G. \& Spengler D. 1998. Serological studies on Corynebacterium pseudotuberculosis infections in goats using enzyme-linked immunosorbent assay. Zentralbl. Veterinärmed. B 45:209-216.

Sutherland S.S., Ellis T.M., Mercy A.R., Paton M. \& Middleton H. 1987. Evaluation of an enzyme-linked immunosorbent assay for the detection of Corynebacterium pseudotuberculosis infection in sheep. Aust. Vet. J. 64:263-266

Ter Laak E.A., Bosch J., Bijl G.C. \& Schreuder B.E.C. 1992. Double-antibody sandwich enzyme-linked immunosorbent assay and immunoblot analysis used for control of caseous lymphadenitis in goats and sheep. Am. J. Vet. Res. 53:1125-1132.

Unanian M.M., Feliciano-Silva A.E.D. \& Pant K.P. 1985. Abscesses and caseous lymphadenitis in goats in tropical semi-arid north-east Brazil. Trop. Anim. Health. Prod. 17:57-62. 